\title{
Retroviral transfer and expression of the interleukin-3 gene in hemopoietic cells
}

\author{
Peter M.C. Wong, Siu-Wah Chung, ${ }^{1}$ and Arthur W. Nienhuis \\ Clinical Hematology Branch, National Heart, Lung, and Blood Institute, National Institutes of Health, \\ Bethesda, Maryland 20892 USA $^{1}$ Laboratory of Genetics, National Cancer Institute, National Institutes of Health, \\ Bethesda, Maryland 20892 USA
}

\begin{abstract}
A recombinant retrovirus containing the interleukin-3 (IL3) coding sequence and the neomycin-resistance gene $\left(\mathrm{Neo}^{\mathrm{r}}\right)$ has been generated. Infection of fetal liver cells with the IL3 retrovirus, but not with the N2 parental virus, resulted in the formation of factor-independent, $\mathrm{Ne}^{\mathrm{R}}$ colonies containing various types of differentiated hemopoietic cells. Established cell lines could be generated from these mixed hemopoietic colonies. These cell lines contained the unrearranged viral genome, produced viral IL3, and secreted the growth factor; however, they were not tumorigenic. Identical results were obtained from infection of two factor-dependent cell lines with the IL3 virus, except that these clones all became tumorigenic. These data indicate that endogenous IL3 production can support normal differentiation and immortalization of primary hemopoietic cells, or, in previously immortalized cells, can lead to tumorigenicity.
\end{abstract}

[Key Words: Retrovirus; gene expression; hemopoietic growth factor; retroviral gene transfer; hemopoietic stem cell differentiation]

Received January 29, 1987; revised version received and accepted April 1, 1987.

A pluripotent stem cell has immense proliferative capacity. It also has the ability to self-renew or to differentiate. In the very dynamic hemopoietic system, the balance between self-renewal and differentiation has to be very flexibly, but properly, controlled. This control appears to be influenced by many growth factors that act on hemopoietic progenitor cells (for reviews, see Metcalf 1984; Stanley and Jubinsky 1984). Among these, interleukin-3 (IL3) and granulocyte-macrophage colony-stimulating factor (GM-CSF) have been shown to play important roles in maintaining the survival, proliferation, and/or differentiation of multipotent stem cells (Sieff et al. 1985; Suda et al. 1985; Metcalf et al. 1986; Tomonaga et al. 1986).

Various hemopoietic cell lines that are dependent on hemopoietic growth factors have been established (Dexter 1980; Greenberger 1983). Dependence on growth factors can often be eliminated after infection with an oncogenic retrovirus containing either the v-abl gene (Oliff et al. 1985; Cook et al. 1985; Pierce et al. 1985) or the v-myc gene (Rapp et al. 1985). At the same time, such cells become tumorigenic. Our recent studies (Wong and Eaves 1987) indicate that primary hemopoietic cells infected with Abelson murine leukemia virus (Ab-MLV) exhibit an initial feeder-dependent phase prior to development of transformed, tumorigenic cell lines. During the phase of feeder-cell dependence, but not at a later stage, a responsiveness to conditioned medium (CM) containing various hemopoietic growth factors was noted (Chung et al. 1986). The factor-independent clones that we have derived from primary hemopoietic cells by introduction of the $\mathrm{v}-a b l$ gene produce GM-CSF, B-cell growth factor, and an unknown factor, but not IL3 (Chung et al. 1986; Chung et al., unpubl.). Recently, a retrovirus capable of transferring the GM-CSF coding sequence was shown to convert FDC-P1 factor-dependent cells to factor-independent tumorigenic cells (Lang et al. 1985). These data suggest that production of hemopoietic growth factors by cells that respond to such factors might play a role in the multistep process of leukemogenesis.

In view of the important role of growth factors in hemopoietic stem cell differentiation, as well as their possible role in leukemogenesis, we chose to generate hightiter recombinant retrovirus containing the IL 3 coding sequence. IL3 was chosen because of its ability to act on pluripotent progenitor cells and on cells of various hemopoietic lineages (Ihle et al. 1983). Our basic purpose was to compare the consequences of endogenous IL3 production in immortalized but previously factor-dependent cell lines and in primary hemopoietic progenitors that are committed to undergo terminal differentiation. In both cases, IL 3 production eliminates the need for the exogenous growth factor. Previously immortalized cell lines become tumorigenic, whereas primary hemopoietic cells retain their capacity to undergo differentia- 
tion into clonal colonies. Immortalized cell lines may be derived from such colonies with high frequency, although these are nontumorigenic.

\section{Results}

\section{Generation of IL3 retrovirus}

As shown in Figure 1, we inserted the IL3 coding sequence into the N2 viral vector. This vector gives hightiter stocks that can be used successfully to infect various hemopoietic cells, including early progenitors (Eglitis et al. 1985; Keller et al. 1985). To generate the recombinant retrovirus, a XhoI fragment was isolated from the pCD-IL3 plasmid (a gift from Dr. Kinichi-Arai, DNAX, Palo Alto, California). This fragment contains both a $5^{\prime}$ splice junction and two $3^{\prime}$ splice junctions of the 16S and 19S SV40 late mRNA located upstream from the IL3 coding sequence (Okayama and Berg 1983). The fragment was cloned into the $\mathrm{N} 2$ vector in the transcriptional orientation such that the expression of IL3 CDNA is driven by the viral long terminal repeat (LTR) (designated N2-IL3 in Fig. 1).

The recombinant vectors were transfected into the $\psi 2$ packaging cell line to produce helper-free virus. After 10 days selection in the neomycin analog, G418, seven to twelve $\mathrm{Neo}^{\mathrm{R}}$ colonies for each vector were removed and expanded, and the supernatants from each of these individual clones were collected. After infection of NIH-3T3 cells, four such supernatants from N2-IL3 lines gave titers between $10^{5}$ and $10^{7} \mathrm{Neo}^{\mathrm{R}}$ colony-forming units (cfu) per milliliter. FDC-P1 cells, which are known to respond to both IL3 and GM-CSF (Hapel et al. 1984), were cultured in the presence of supernatants from the producer clones, and $\left[{ }^{3} \mathrm{H}\right]$-thymidine uptake was determined (Fig. 2). Supernatants of seven of the N2-IL3 clones had the same level of IL3 activity as the WEHI-3 cell line, which is known to produce IL3 (data not shown|. Supernatants from N2 producer clones did not stimulate the target cells above background. To establish more firmly that the stimulating activity detected on FDC-P1 cells is due to the presence of IL3, a methylcellulose stem cell clonogenic assay on adult bone marrow cells was performed. Supernatants from two clones of the N2-IL3 vector examined were both found
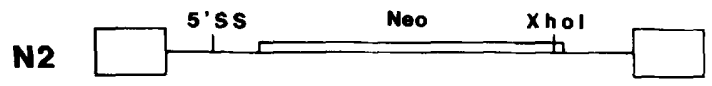

N2-IL3

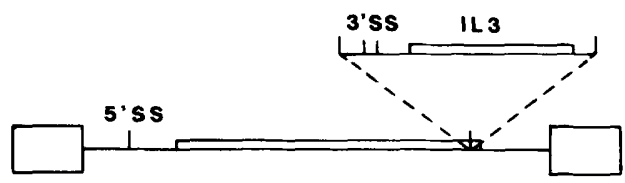

Figure 1. Diagram of the IL-3 retroviral recombinant vectors. N2 vector is the parent vector obtained from E. Gilboa. Open boxes represent LTR sequence. (5' SS) $5^{\prime}$ splice signal; (3' SS) 3' splice signal. Not depicted in the diagram is the presence of an additional 5' SS in the XhoI fragment of the N2-IL3 construct.

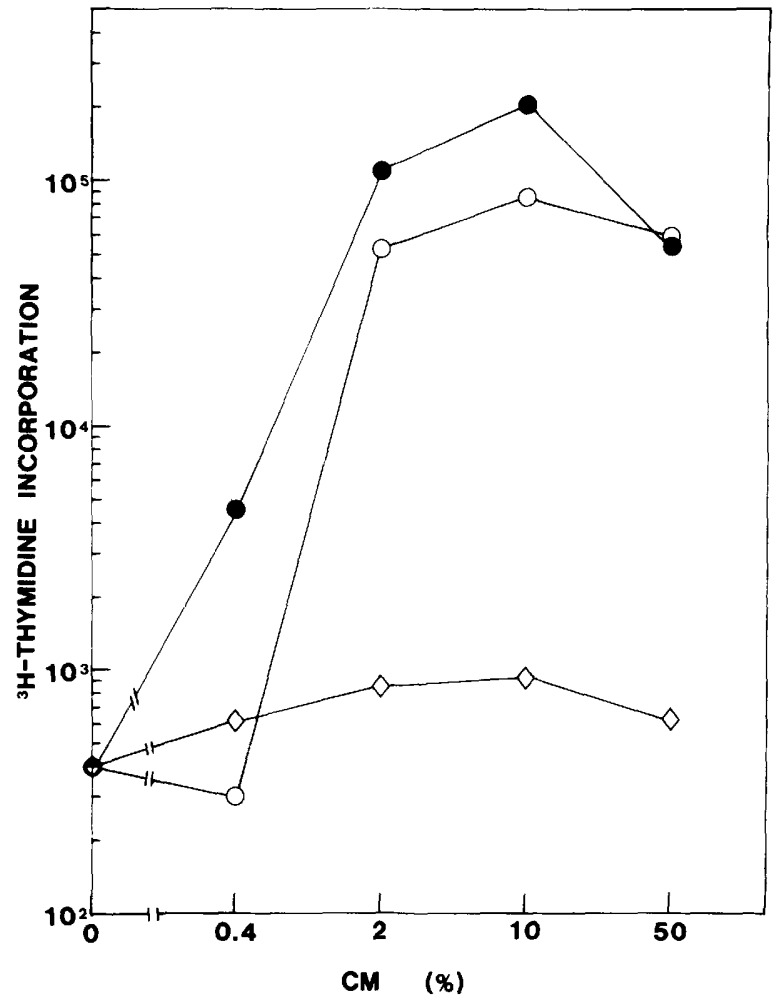

Figure 2. Growth factor production by N2 or N2-IL3 producer cells. $\left[{ }^{3} \mathrm{H}\right]$ Thymidine uptake by FDC-Pl cells was measured in response to various amounts of conditioned medium (CM). CM supernatants from various producer clones were tested and the results for two clones of N2-IL3, clone $6(O)$ and clone $9(0)$ and one clone of N2 $|\diamond|$ producers are shown.

to support growth of various hemopoietic colonies, including erythroid, macroscopic-mixed, granulocytemacrophage, and mast cell types. These colony-stimulating activities are equivalent to those of IL3 (Ihle et al. 1983; Metcalf 1984). Thus, we conclude that both the IL3 and the $\mathrm{NeO}^{\mathrm{r}}$ genes present in the retroviral genome are intact and properly expressed to give rise to a functional protein in over $90 \%$ of the producer clones selected.

\section{Infection of hemopoietic progenitor cells from fetal liver}

Fetal liver progenitor cells were infected with the N2-IL3 virus. As shown in Table 1 such infection resulted in the formation of various types of hemopoietic colonies, including erythroid $\{S+L$ BFU-E , erythroidmix ( $\mathrm{E} \mathrm{mix)}$, as well as nonerythroid (non-E) type. In contrast to cultures from uninfected fetal liver cells, colonies from N2-IL3 virus-infected fetal liver cells could be generated in the absence of added growth factor and they were found to be G418 resistant. The overall frequency for generation of these factor-independent $\mathrm{Neo}^{\mathrm{R}}$ colonies was close to $35 \%$, with experimental variation ranging between 20 and $50 \%$. This frequency could be increased further by cocultivating the fetal liver cells with the virus producer cells (data not shown). Factor-independent, G418-resistant hemopoietic colonies were 
Table 1. Formation of factor-independent, G418-resistant colonies after infection of day-12 fetal liver cells with N2 and N2IL3 virus

\begin{tabular}{|c|c|c|c|c|c|c|}
\hline \multirow[b]{2}{*}{ Virus } & \multirow{2}{*}{$\begin{array}{c}\text { Heat } \\
\text { inactivation }\end{array}$} & \multirow[b]{2}{*}{ SCM } & \multirow[b]{2}{*}{ G418 } & \multicolumn{3}{|c|}{ Number of colonies $\mathrm{b} / 7 \times 10^{4}$} \\
\hline & & & & $\mathrm{S}+\mathrm{L} \quad$ BFU-E & E-mix & Non-E \\
\hline \multirow[t]{8}{*}{ N2-1L3 } & - & + & - & $7 \pm 2(100)$ & $13 \pm 5(100)$ & $178 \pm 17(100)$ \\
\hline & & - & - & $4 \pm 2 \quad(57)$ & $5 \pm 1 \quad|38|$ & $97 \pm 2$ \\
\hline & & - & + & $4 \pm 2 \quad(57)$ & $3 \pm 1$ & $60 \pm 14$ \\
\hline & & + & + & $4 \pm 1 \quad(57)$ & $6 \pm 2 \quad|46|$ & $94 \pm 21$ \\
\hline & + & + & - & $6 \pm 2 \quad(100)$ & $15 \pm 5(100)$ & $155 \pm 6 \quad(100)$ \\
\hline & & - & - & $1 \quad(16)$ & 0 & $5 \pm 3$ \\
\hline & & - & + & 0 & 0 & 0 \\
\hline & & + & + & 0 & 0 & 0 \\
\hline \multirow[t]{8}{*}{ N2 } & - & + & - & $4 \pm 2 \quad(100)$ & $11 \pm 2(100)$ & $142 \pm 13(100)$ \\
\hline & & - & - & $3 \pm 1 \quad|75|$ & 0 & 0 \\
\hline & & - & + & $1 \quad|25\rangle$ & 0 & 0 \\
\hline & & + & + & $2 \pm 1 \quad\langle 50\rangle$ & $3 \pm 1 \quad(27)$ & $74 \pm 6 \quad|52|$ \\
\hline & + & + & - & $4 \pm 2 \quad(100)$ & $10 \pm 2(100)$ & $111 \pm 14(100)$ \\
\hline & & - & - & $1 \quad(25)$ & 0 & 0 \\
\hline & & - & + & 0 & 0 & 0 \\
\hline & & + & + & 0 & 0 & 0 \\
\hline
\end{tabular}

a Heat inactivation was done by incubation at $56^{\circ} \mathrm{C}$ for $1 \mathrm{hr}$.

b All cultures contained 1 unit/ml of erythropoietin (Amgen). Criteria for scoring various types of colonies have been described previously (Wong et al. 1986). (S + L BFU-E) Small and large erythroid bursts; (E-mix) erythroid-mixed; (non-E) nonerythroid. All values are average numbers of colonies per dish in triplicates from a single experiment \pm 1 SEM. This experiment has been repeated twice and similar results were obtained. Numbers in parentheses are relative plating efficiencies.

not observed in cultures of fetal liver cells exposed to the heat-inactivated IL3 virus stock (Table 1). To demonstrate that the factor-independent nature of the colonies formed is specifically due to the IL 3 gene in the recombinant virus, we also infected fetal liver cells with N2 virus, which contains the $\mathrm{Neo}^{\mathrm{r}}$ gene only. $\mathrm{Neo}^{\mathrm{R}}$ colonies were formed only when spleen cell conditioned medium (SCM) containing IL3 was added to the cultures (Table 1). Thus, our data indicate that factor-independent differentiation occurs after efficient delivery of the IL3 gene into hemopoietic progenitor cells.

We next successfully passaged individual colonies of the $\mathrm{E}$ mix and the mast cell type, but not others, into cell lines (10/12 E-mix, 7/7 mast, 0/6 CFU-GM, 0/4 BFU-E). As a control, E-mix and mast cell colonies from the uninfected cultures were picked and placed in WEHI-3 conditioned medium containing IL3; a similar frequency of cell lines was observed ( $7 / 8 \mathrm{mix}, 6 / 6 \mathrm{mast})$. Examination of three randomly chosen lines derived from E-mixed colonies after N2-IL3 infection revealed a mast cell phenotype, as determined by Wright stain. The conditioned media from each of the cell lines contained an activity that stimulated proliferation of FDC-P1 cells (Fig. 3). To demonstrate more firmly that the factor produced was IL3, we performed Southern blot and S1 analysis to document the presence of the viral IL3 gene as well as the corresponding mRNA. For Southern analysis, DNAs from four such lines (FL-1, -2, -5, and -9) were digested with SacI, an enzyme with recognition sequences located in the LTR region of the N2-IL3 vector, thus releasing the whole $4.4-\mathrm{kb}$ band representing the viral genome. When the DNA was hybridized with an
IL3 probe, a fragment of the $6.6-\mathrm{kb}$ band representing the endogenous IL3 gene was present in all cell lines (Fig. 4a). All four lines contained an additional band with the expected size of $4.4 \mathrm{~kb}$, indicating the presence of the integrated, complete N2-IL3 viral genome. When the DNA was hybridized with a Neo ${ }^{\mathrm{r}}$ probe, the same $4.4-\mathrm{kb}$ band that hybridized with the IL3 probe was observed in all four FL lines but not in the negative-control 32D lines (Fig. 4b). End-labeled probe, S1 analysis on RNA samples of four such lines demonstrated that the viral IL3 gene, but not the endogenous counterpart, was expressed, as indicated by the presence of protected 223 . and 157-nucleotide fragments derived from spliced RNA (Fig. 5). Northern blot analysis using an IL3 coding sequence probe demonstrated species of $1.2,2.3$, and 4.4 $\mathrm{kb}$ in length. The latter is a full-length genomic transcript whereas the others represent subgenomic spliced species that may terminate at the SV40 poly(A) site in the vector.

\section{Infection of factor-dependent cells}

It has recently been shown that infection of factor-dependent FDC-P1 cells with a recombinant GM-CSF virus results in factor-independent growth (Lang et al. 1985). To examine whether our N2-IL3 virus can also eliminate factor dependence, we infected two IL3-dependent cell lines-32D and FDC-P1. G418-resistant and factor-independent growth could be observed in cultures of the infected, but not of the uninfected, 32D and FDC-P1 cells (data not shown). After 2 weeks in methylcellulose culture, factor-independent cell lines were obtained from these colonies. Supernatants from these 


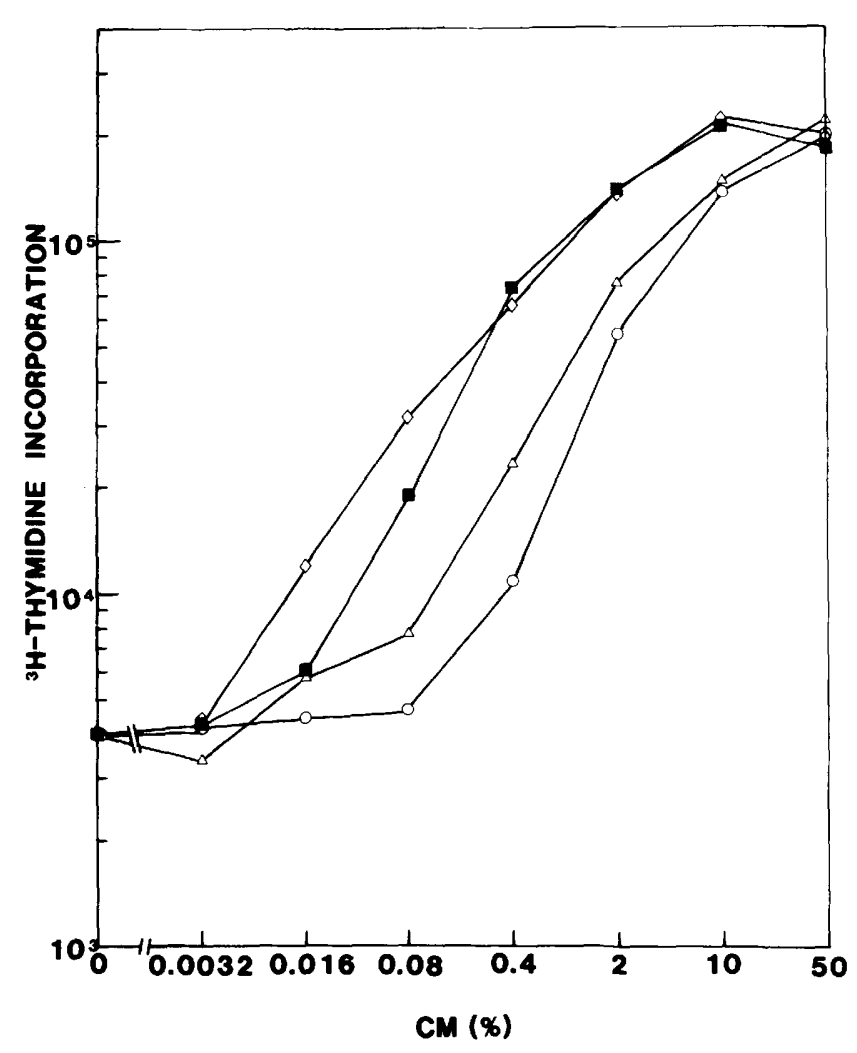

Figure 3. Growth factor production by N2-IL3-infected fetal liver cell lines (FL-1, -5 , and -9). Dose-response curve of $\left[{ }^{3} \mathrm{H}\right]$ thymidine uptake by FDC-Pl cells. Supernatants are from the infected fetal liver cells. All values are means of triplicate cultures. (口) WEHI; (O) FL- 1 ; $(\Delta)$ FL-5; $(\diamond)$ FL-9.

cells infected with N2-IL3 stimulated proliferation of the parental FDC-P1 cells, indicating production of growth factors (data not shown). Again, Southern blot analysis demonstrated the presence of the unrearranged integrated viral genome containing both the $\mathrm{Neo}^{\mathrm{r}}$ and IL3 genes (data not shown). S1 analysis indicated production of the spliced IL3 mRNA (data not shown). Similar

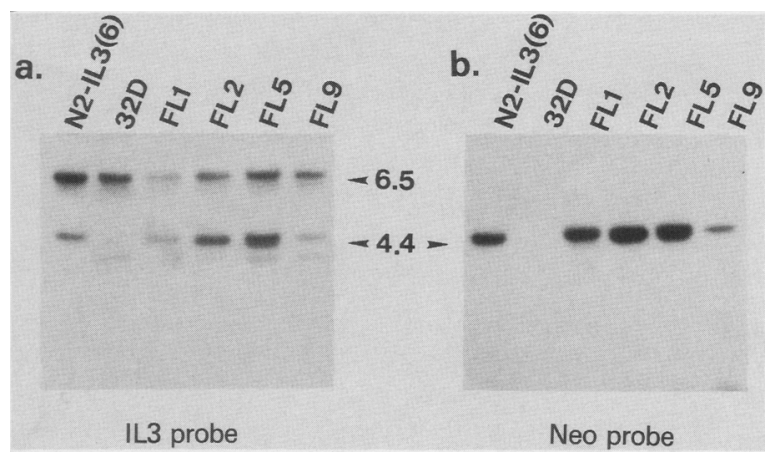

Figure 4. Presence of the integrated viral genome in N2-IL3infected fetal liver FL lines (FL-1, -2, -5, and -9). SacI-digested DNA from the N2-IL3-infected 32D producer cells, uninfected $32 \mathrm{D}$ cells, as well as the various clones of the N2-IL3 infected fetal liver cells were reacted with probes to either IL3 or $\mathrm{Neo}^{\mathrm{R}}$. data were obtained from Northern analysis of RNA from infected FDC-Pl cells, indicating the presence of at least three IL3-related transcripts (Fig. 6).

Factor-independent $32 D$ and FDC-P1 but not fetal liver cell lines are tumorigenic

To examine whether the N2-IL3 virus confers tumorigenic properties to both the primary fetal liver-derived FL lines and the secondary 32D factor-independent CL31 cell lines, we injected 10 million cells each from various clones into individual nude mice and observed tumor development (Table 2). All mice injected with cells derived from fetal liver cells (FL-1, -5, -9) did not develop tumors, even 7 months after inoculation. In contrast, all mice that received any of three clones of factor-independent $32 \mathrm{D}$ cells $(\mathrm{Cl} 31 \mathrm{a}, \mathrm{b}, \mathrm{c})$ developed tumors at the site

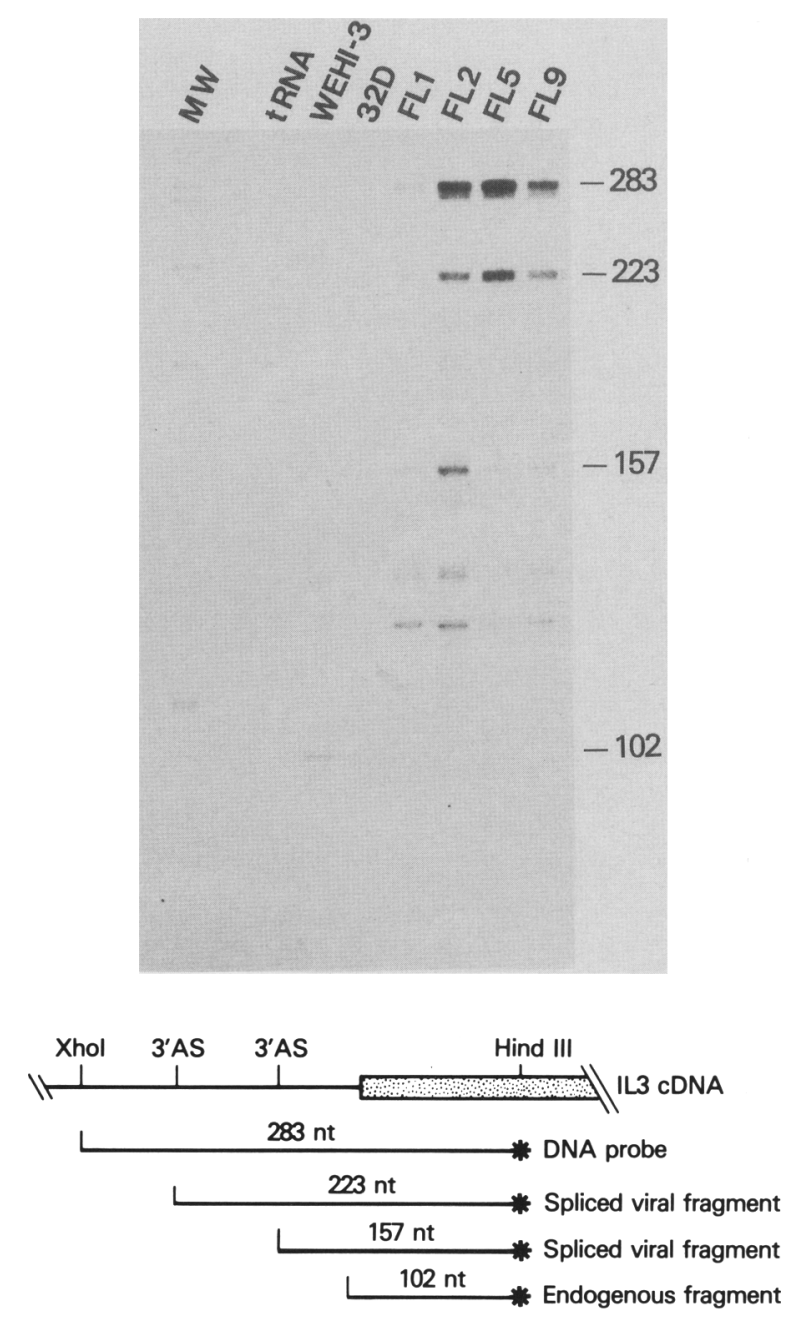

Figure 5. Presence of viral IL3 mRNA in N2-IL3-infected fetal liver cell lines (FL-1, -2, -5, and -9). An S1 nuclease protection assay was done on RNA samples from various cell lines. The HindIII-XhoI fragment of pCD-IL3 was $5^{\prime}$ end-labeled as described in Maniatis et al. (1982). Several experiments indicated that all other bands were of nonspecific background. These nonspecific bands are probably due to nicking of the larger protected fragment, which contains high GC as well as AT-rich clusters. 


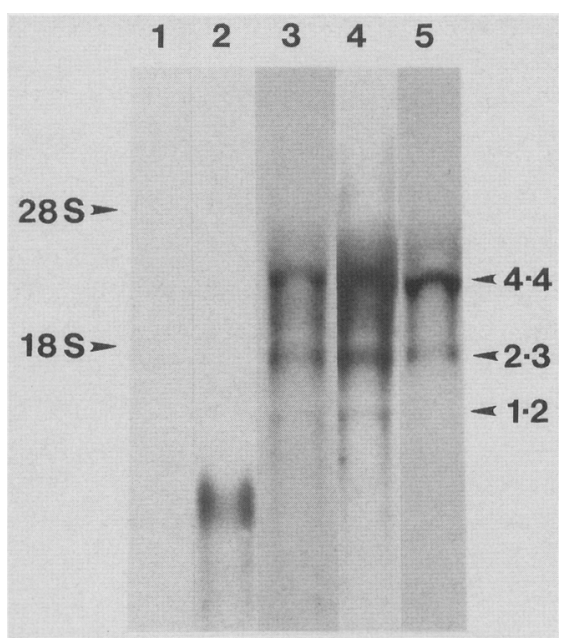

Figure 6. Northern analysis of RNA from FDC-P1 cells infected with the N2-IL3 virus. Fifteen micrograms of total cellular RNA of each sample was added to each lane. (Lane 1) FDC-P1 cells; (lane 2) WEHI-3 cells; (lanes 3-5) FDC-P1 cells infected with N2-IL3 virus (FI-1, -8 , and -11, respectively).

of injection beginning on the third week, with all mice dying by 8 weeks. No mice receiving the uninfected parental 32D cells developed tumors during 20 weeks of observation. Mice injected with the parental FDC-P1 cells also did not develop tumors, but those infected with IL3 virus-infected FDC-P1 cells all developed tumors and died 8 weeks later. Autopsies were performed. The lymph nodes and spleen were enlarged massively, and distinct pale colonies appeared on the surface of the enlarged spleen. Bone marrow was hyperplastic but pale in color.

Karotype analysis was carried out to document whether there were any chromosomal changes in these

Table 2. Incidence of tumor formation in nude mice

\begin{tabular}{lc}
\hline Cell type & $\begin{array}{c}\text { Number of mice } \\
\text { with tumor/total } \\
\text { number of mice }\end{array}$ \\
\hline $32 D$ & $0 / 6$ \\
CL31 a & $6 / 6$ \\
$\quad$ b & $6 / 6$ \\
c & $6 / 6$ \\
FDC-P1 & $0 / 5$ \\
FI-1 & $5 / 5$ \\
8 & $5 / 5$ \\
11 & $5 / 5$ \\
FL-1 & $0 / 4$ \\
5 & $0 / 4$ \\
9 & $0 / 4$ \\
\hline
\end{tabular}

CL31 and FI lines were obtained by infecting 32D and FDC-P1 cells, respectively, with the IL3 virus. FL lines were derived from N2-IL3 virus-infected colonies in fetal liver cultures. A total of $10^{7}$ cells were injected subcutaneously into $8-$ to 10 week-old BALB/c nude mice. Tumor formation was recorded 4 weeks after inoculation. factor-dependent cells after IL 3 virus infection and to document the origin of the tumorigenic cells. As shown in Figure 7a, FDC-P1 is a hypodiploid mouse cell line. The modal chromosome number is 32 , occurring in $56 \%$ of metaphases examined, and the frequency of polyploid cells (i.e., the chromosome number close to or more than twice the modal number) is $3.4 \%$. There are a total of 12 marker chromosomes, two of which, however, are specific to subpopulations. Three karyotypically distinct subpopulations were identified: (1) FDC-P1-a (Fig. 7a) has one normal chromosome 12 and M11; (2) FDC-P1-b lacks a normal chromosome 12 but has the iso-chromosome 12; and (3) FDC-P1-c lacks both normal chromosomes 12 and M11, but has a different marker M12. These subpopulations were represented at frequencies of $50 \%, 24 \%$, and $26 \%$, respectively, in the 50 spreads analyzed. Normal chromosomes 2, 5, and 7 were absent. The Y chromosome is absent, and only one normal X was detected.

The karyotype of FI-1 is identical to that of an FDC subpopulation, FDC-P1-c (Fig. 7b). No other coexisting subpopulations were detected at the level of 50 metaphase analyses. As expected, FI-ln, tumor cells derived from mice injected with FI-1, have an identical karyotype to FI-1 and also lack a karyotypically distinguishable subpopulation. Similar results were obtained on analysis of another clone. Thus, we have demonstrated absence of additional chromosome changes at the karyotype level after IL3 virus infection. We have also demonstrated that the tumors generated in nude mice were derived from the donor FDC-P1(FI) cells.

\section{Discussion}

Our studies indicate that endogenous production of IL3, after retrovirus-mediated gene transfer, has very different consequences, depending on whether the gene is introduced into primary hemopoietic cells or into those already adapted for growth in culture. Production of IL3 in various progenitor cells leads to apparently normal proliferation and differentiation, as defined by a formation of factor-independent clonal colonies identical to those derived from uninfected progenitors in the presence of exogenous growth factors. Immortalized mast cells can be derived from such factor-independent colonies analogous to the establishment of mast cell lines by constant exposure of normal bone marrow cells to medium containing IL3. The mast cell lines that are derived based on endogenous IL3 production are nontumorigenic when injected into nude mice. Retrovirus-mediated transfer of the IL3 gene into established cell lines such as 32D and FDC-P1 leads to conversion from a nontumorigenic to a frankly neoplastic state coincident with acquisition of factor independence, as reflected by formation of tumors in nude mice. Since 32D and FDC-P1 cells are karyotypically abnormal prior to introduction of the IL3 gene, it is reasonable to conclude that additional genetic changes had already occurred in these cells predisposing to progression to malignancy once a factor-independent state was established. In contrast, at- 

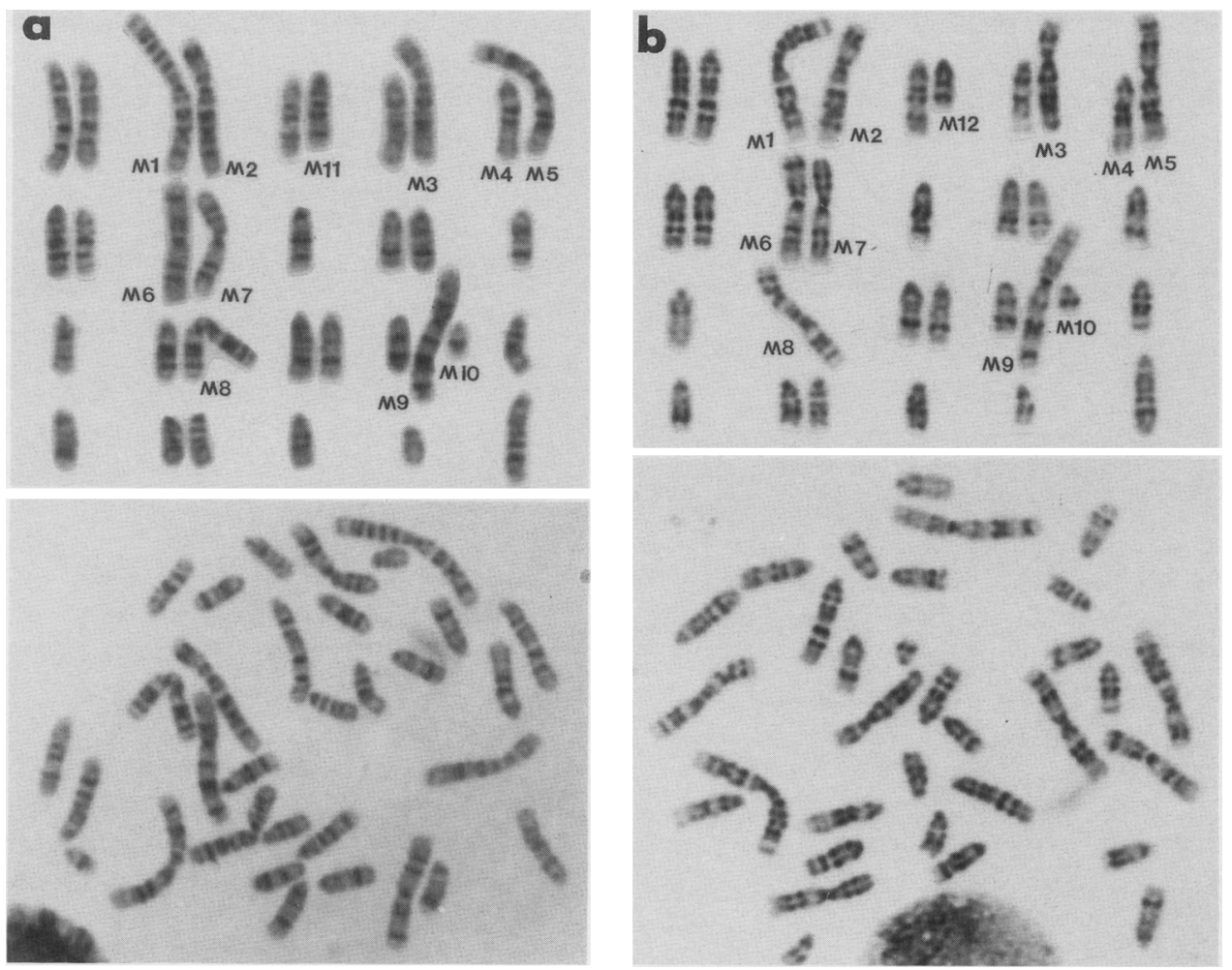

Figure 7. Karyotype analysis of FDC-P1 cells $(a)$ and N2-IL3 virus-infected FDC-P1 cells, FI-1 $(b)$.

taining factor-independence is, by itself, insufficient to convert normal cells directly to the malignant state.

Factor-independent growth of established hemopoietic cell lines has previously been shown to be closely related to the acquisition of tumorigenicity. Both the Abelson virus and a recombinant virus containing GM-CSF coding sequences convert factor-dependent cells to factor independence and tumorigenicity (Cook et al. 1985; Oliff et al. 1985; Lang et al. 1985). In one instance, infection of primary hemopoietic cells with Abelson virus has led to the same result (Wong et al. 1987). Rarely, tumorigenic, factor-independent cell lines can also be obtained after fresh bone marrow cells have been passaged in the presence of IL 3 for several months (Ball et al. 1983; Schrader and Crapper 1983). Presumably, prolonged growth of these marrow cells in culture allowed evolution and selection of highly abnormal clones. In contrast, in our experiments, infection of primary fetal liver hemopoietic progenitor cells with the N2-IL3 virus resulted, within a few weeks, in frequent generation of factor-independent mast cell lines incapable of forming tumors. We attribute the acquisition of tumorigenicity by $32 \mathrm{D}$ and FDC-P1 cells to the presence of undefined mutations that, in the absence of endogenous IL3, result in immortalization without tumorigenicity, but along with endogenous IL3 production result in tumor formation. The amount of IL3 produced by the nontumorigenic mast cell lines derived from fetal liver and tumorigenic cell lines derived from previously immortalized cells was equivalent, as tested once and judged by the ability of conditioned medium to support the growth of factor-dependent cells (Fig. 3 and P.M.C. Wong, unpubl.). Thus, factor independence can be disassociated from the acquisition of tumorigenicity.

Endogenous production of IL3 did not demonstrably affect self-renewal of primary multipotent progenitor cells. Proliferation of various hemopoietic progenitors to form colonies of mature precursors was supported by endogenous IL3 production without alteration in the type or cellular composition of colonies compared with colonies formed by uninfected progenitor cells in the presence of exogenous growth factors. The mechanism by which IL3 influences cell differentiation, whether permissive or inductive, is controversial (Suda et al. 1986; Koike et al. 1986; Spivak et al. 1985) and not resolved by our experiments. Replating of early-passage cell lines, derived from mixed or mast colonies, in methylcellulose gave rise to mast colonies but no mixed colonies, indicating that endogenous IL3 did not have a dramatic effect on self-renewal of primitive multipotential hemopoietic progenitors in vitro. Emergence of mast cells in extended cultures may simply reflect the fact that such mature cells retain proliferative capacity in contrast to erythroid, granulocytic, and monocytic cells.

Endogenous expression of the IL 3 gene in progenitor cells is likely to mediate factor-independent growth through a factor-receptor autocrine mechanism (Sporn and Todaro 1980; Schrader and Crapper 1983; Adkins et al. 1984). The presence of IL3 in medium conditioned by such cells is consistent with this mechanism. As IL3 re- 
ceptors are present in 32D and FDC-P1 cells (Palaszynski and Ihle 1984), factor-independent growth of such cells also seems most consistent with an autocrine mechanism, although this supposition has not been tested directly.

\section{Materials and methods}

Animals and cells

Six- to ten-week-old BALB/c, NIH/Swiss, or BALB/c nude mice were obtained either from the small animal facility of the $\mathrm{Na}$ tional Institutes of Health or from the National Cancer Institute (Frederick, Maryland). Single-cell suspensions of day-12 fetal liver were prepared as described in Wong et al. (1983). The bone marrow-derived FDC-P1 myeloid lineage cells (Dexter et al. 1980) and 32D mast-lineage cells (Greenberger et al. 1983) were maintained in RPMI- 1640 supplemented with $10 \%$ fetal calf serum (FCS) and 10\% WEHI-3B conditioned medium. The $\psi 2$ and 3 T3 cells were maintained in improved modified Eagle's medium supplemented with $10 \%$ calf serum and FCS, respectively. All factor-independent cells were passaged using RPMI-1640 supplemented with $10 \%$ FCS and $50 \mu \mathrm{M} 2$-mercaptoethanol.

\section{Construction of recombinant N2-IL3 retrovirus}

The pCD expression vector containing the IL3 cDNA was kindly provided by Dr. Kinichi Arai (DNAX, Palo Alto, California). To generate the N2-IL3 recombinant, the $1.2-\mathrm{kb} X$ hoI fragments of pCD-IL3 containing the IL3 coding sequence as well as a $5^{\prime}$ splice site and two $3^{\prime}$ splice sites were cloned into the N2 vector kindly provided by Dr. Eli Gilboa (Princeton University|.

\section{Transfection and infection}

DNA $(10 \mu \mathrm{g})$ was transfected into $\psi 2$ packaging cells (Mann et al. 1983) by the method of Graham and van der Eb (1973). G418 at an active concentration of $400 \mu \mathrm{g} / \mathrm{ml}$ was added to the medium $24 \mathrm{hr}$ after the transfection. Approximately 2 weeks later, resistant colonies were expanded individually and supernatant from the clones was collected to determine the concentration of infectious viral particles and the amount of growth factor present. To determine the titer of infectious virus, $10^{5}$ exponentially growing $3 \mathrm{~T} 3$ cells were seeded onto $60-\mathrm{mm}$ tissue culture dishes. The next day, $0.5-1.0 \mathrm{ml}$ of viral supernatant containing $10 \mu \mathrm{g} / \mathrm{ml}$ Polybrene (Sigma) was added to the dish after removal of spent medium. After $2 \mathrm{hr}$ incubation with occasional shaking, $4 \mathrm{ml}$ of fresh medium was added directly. The next day, the medium was replaced with another $4 \mathrm{ml}$ of medium containing $1 \mathrm{mg} / \mathrm{ml} \mathrm{G} 418$ (active concentration). G418resistant colonies were scored 12 days later. Supernatant infection of fetal liver cells was done by incubating $1-2 \times 10^{6}$ cells with $1 \mathrm{ml}$ of viral supernatant containing $5 \mu \mathrm{g} / \mathrm{ml}$ Polybrene. After an overnight incubation, cells were washed three times and plated in methylcellulose culture. For infecting $32 \mathrm{D}$ cells, coculturing was done; $3 \times 10^{5}$ virus producer cells were plated in $60-\mathrm{mm}$ dishes and $24 \mathrm{hr}$ later, $10^{6} 32 \mathrm{D}$ cells were seeded with $5 \mathrm{ml}$ of fresh medium containing $5 \mu \mathrm{g} / \mathrm{ml}$ Polybrene. The following day, nonadherent cells were harvested, washed three times, and plated in methylcellulose culture.

\section{Southern blot and S1 nuclease analysis}

High-molecular-weight DNA from various clones was prepared (Maniatis et al. 1982) and 10-15 $\mu$ g of DNA was digested with SacI, electrophoresed, transferred onto GeneScreen Plus, and hybridized to either an M13 probe or a nick-translated IL3 or $\mathrm{Neo}^{\mathrm{r}}$ probe. Hybridization was carried out at $65^{\circ} \mathrm{C}$ overnight. Filters were washed $1 \mathrm{hr}$ at $65^{\circ} \mathrm{C}$ in $2 \times \mathrm{SSC} / 1 \%$ SDS followed by $1 \mathrm{hr}$ in $0.1 \times \mathrm{SSC}$ at room temperature. The IL3 probe was either an EcoRI-HindIII fragment from pTZ-IL3 or a XhoIHindIII fragment from pCD-IL3, both of which contain the $5^{\prime}$ end of IL3 cDNA. The Neo ${ }^{r}$ probe was a nick-translated 600 -bp fragment from the pSV2-neo plasmid.

For Sl analysis, total cellular RNA was obtained by lysing approximately $2 \times 10^{8}$ cells in $4 \mathrm{M}$ guanidine thiocyanate solution. This was then overlaid on top of a cushion of $2.5 \mathrm{ml}$ of cesium chloride $(2 \mathrm{~g} / \mathrm{ml})$ in each of six SW-41 tubes. They were then spun at $32 \mathrm{~K}$ for $16 \mathrm{hr}$. The RNA pellet at the bottom was dissolved in water. After two phenol/chloroform extractions, the RNA was precipitated and stored with ethanol at $-70^{\circ} \mathrm{C}$ until used. S1 analysis was carried out according to Ley et al. (1982). Northern analysis was done according to Maniatis et al. (1982).

\section{Methylcellulose culture and proliferation assay}

Day-12 fetal liver cells were prepared and cultured in methylcellulose medium at $37^{\circ} \mathrm{C}$ for $6-8$ days as described previously (Wong et al. 1983, 1982). Adult bone marrow cells as well as $32 \mathrm{D}$ cells were cultured similarly, except the duration of incubation was 10-14 days. In culturing 32D cells, WEHI-3B-conditioned medium (at an optimal final concentration of $10 \%$ ) was used in place of SCM (a final optimal concentration of $1 \%$ was used) and erythropoietin (Epo) at a final concentration of 1 unit $/ \mathrm{ml}$ was not added. The preparation of SCM was done according to the following. Single-cell suspension in alpha medium (Gibco) was prepared from pooled spleens of 8- to 12week-old BALB/c mice. Cell concentration was adjusted and added to the culture mixture in a final concentration of $4 \times 10^{6} / \mathrm{ml}$. The culture mixture was in alpha medium, which contains $1: 300$ dilution of the pokeweed mitogen stock (Gibco), 1\% bovine serum albumin (Gibco), and $10^{-4} \mathrm{M}$ of 2 mercaptoethanol. After 4 days of incubation at $37^{\circ} \mathrm{C}$ in a humid incubator with $5 \% \mathrm{CO}_{2}$, the supernatant was harvested after centrifugation $(1000 \mathrm{~g})$. Aliquots were made and stored at $-20^{\circ} \mathrm{C}$ until used. The optimal activity was determined by both the cell proliferation assay and the clonogenic assay. The source of Epo (1 unit $/ \mathrm{ml}$ culture) used was TcEpo from Amgen (California). Scoring criteria for various colonies were described previously (Wong et al. 1986). Proliferation assays based on $\left[{ }^{3} \mathrm{H}\right]$ thymidine incorporation was done according to Chung et al. (1986). Conditioned media from various cell lines was collected by harvesting media exposed to cells after 2-3 days of incubation at an initial concentration of $1-5 \times 10^{5}$ cells $/ \mathrm{ml}$.

\section{Acknowledgments}

We would like to thank T.R. Chen (ATCC, Rockville, Maryland) for performing the karyotype analysis; Mary McMahon and Rhonda Mays for secretarial assistance; Sandy Ruscetti for critically reading our manuscript; Stefan Karlsson, Frank Ruscetti, and Linda Wolfe for interest in our work; and Sandy Ruscetti and Timothy R. Rutherford for helpful discussion. P.M.C.W. is a National Cancer Institute of Canada Senior Postdoctoral Fellow. S.W.C. is an International Fogarty Visiting Fellow.

\section{References}

Adkins, B., A. Leutz, and T. Graf. 1984. Autocrine growth induced by src-related oncogenes in transformed chicken myeloid cells. Cell 39: 439-445. 
Ball, P.E., M.C. Conroy, C.H. Heusser, J.M. Davis, and J.F. Conscience. 1983. Spontaneous, in vitro, malignant transformation of a basophil/mast cell line. Differentiation 24: 74-78.

Chung, S.W., P.M.C. Wong, G. Sheng-Ong, S. Ruscetti, T. Ishizaka, and C.J. Eaves. 1986. Production of granulocyte-macrophage colony stimulating factor (GM-CSF) by Abelson virus induced tumorigenic mast cell lines. Blood 68: 10741081.

Cook, W.D., D. Metcalf, N.A. Nicola, A.W. Burgess, and F. Walker. 1985. Malignant transformation of a growth factordependent myeloid cell line by Abelson virus without evidence of an autocrine mechanism. Cell 41: 677-683.

Dexter, T.M., J. Garland, D. Scott, E. Scolnick, and D. Metcalf. 1980. Growth of factor-dependent hemopoietic precursor cell lines. I. Exp. Med. 152: 1036-1047.

Eglitis, M., P. Kantoff, E. Gilboa, and W.F. Anderson. 1985 Gene expression in mice after high efficiency retroviral-mediated gene transfer. Science 230: 1395-1398.

Graham, F.L. and A.J. van der Eb. 1973. A new technique for the assay of infectivity of human adenovinus 5 DNA. Virology 52: $456-467$

Greenberger, J.S., M.A. Sakakeeny, R.K. Humphries, C.J. Eaves, and R.J. Eckner. 1983. Demonstration of permanent factordependent multipotential (erythroid/neutrophil/basophil) hematopoietic progenitor cell lines. Proc. Natl. Acad. Sci. 80: $2931-2935$.

Happel, A.J., H.S. Warren, and D.A. Hume. 1984. Different colony-stimulating factors are detected by the "interleukin3 "-dependent cell lines FDC-P1 and 32Dcl-23. Blood 64: $786-790$

Ihle, J.N., J. Keller, S. Oroszlan, L. Henderson, T. Copeland, F. Fitch, M.B. Prystowsky, E. Goldwasser, J.W. Schrader, E. Palaszynski, Dym, and B. Lebel. 1983. Biological properties of homogeneous interleukin 3. Demonstration of WEHI-3 growth factor activity, mast cell growth factor activity, Pcell stimulating factor activity, colony stimulating factor activity, and histamine producing cell stimulating factor activity. I. Immunol. 131: 282-287.

Keller, G., C. Paige, E. Gilboa, and E.J. Wagner. 1985. Expression of a foreign gene in myeloid and lymphoid cells derived from multipotent hemopoietic precursors. Nature 318: $149-154$.

Koike, K., J.N. Ihle, and M. Ogawa. 1986. Declining sensitivity to interleukin 3 of murine multipotential hemopoietic progenitors during their development. J. Clin. Invest. 77: 894899.

Lang, R.A., D. Metcalf, N.M. Gough, A.R. Dunn, and T.J. Gonda. 1985. Expression of a hemopoietic growth factor cDNA in a factor-dependent cell line results in autonomous growth and tumorigenicity. Cell 43: 531-542.

Ley, T.J., N.P. Anagnou, G. Pepe, and A.W. Nienhuis. 1982. RNA processing errors in patients with $\beta$-thalassemia. Proc Natl. Acad. Sci. 79: 4775-4779.

Maniatis, T., E.F. Fritsh, and J. Sambrook. 1982. Molecular cloning: A laboratory manual. Cold Spring Harbor Laboratory, Cold Spring Harbor, New York.

Mann, R., R.C. Mulligan, and D. Baltimore. 1983. Construction of a retrovirus packaging mutant and its use to produce helper-free defective retrovirus. Cell 33: 153-159.

Metcalf, D. 1984. The hemopoietic colony stimulating factors. Elsevier, Amsterdam.

Metcalf, D., C.G. Begley, G.R. Johnson, N.A. Nicola, M.A. Vadas, A.F. Lopez, D.J. Williamson, G.G. Wong, S.C. Clark, and E.A. Wong. 1986. Biologic properties in vitro of a recombinant human granulocyte-macrophage colony-stimulating factor. Blood 67: 37-45.
Oliff, A., O. Agranovsky, M.D. McKinney, V.V.V.S. Murty, and R. Banchwitz. 1985. Friend murine leukemia virus-immortalized myeloid cells are converted into tumorigenic cell lines by Abelson leukemia virus. Proc. Natl. Acad. Sci. 82: 3306-3310.

Okayama, H. and P. Berg. 1983. A cDNA cloning vector that permits expression of cDNA inserts in mammalian cells. Mol. Cell. Biol. 3: 280-289.

Palaszynski, E.W. and J.W. Ihle. 1984. Evidence for specific receptors for interleukin 3 on lymphokine-dependent cell lines established from long-term bone marrow cultures. $J$. Immunol. 132: 1872-1878.

Pierce, J.H., P.P. Di Fiore, S.A. Aaronson, M. Potter, J. Pumphrey, A. Scott, and J.N. Ihle. 1985. Neoplastic transformation of mast cells by Abelson MuLV: Abrogation of IL-3 dependence by a nonautocrine mechanism. Cell 41: 685-693.

Rapp, U.R., J.L. Cleveland, K. Brightman, A. Scott, and J.N. Ihle. 1985. Abrogation of IL-3 and IL-2 dependence by recombinant murine retroviruses expressing v-myc oncogenes. $\mathrm{Na}$ ture 317: 434-438.

Schrader, J.W. and R.M. Crapper. 1983. Autogenous production of a hemopoietic growth factor "P cell stimulating factor" as a mechanism for transformation of bone marrow-derived cells. Proc. Natl. Acad. Sci. 80: 6892-6896.

Sieff, C.A., G.G. Emerson, R.E. Donahue, D.G. Nathan, E.A. Wang, G.G. Wong, and S.C. Clark. 1985. Human recombinant granulocyte-macrophage colony-stimulating factor: A multilineage hematopoietin. Science 230: 1171-1173.

Spivak, J.L., R.R.L. Smith, and J.N. Ihle. 1985. Interleukin 3 promotes the in vitro proliferation of murine pluripoten hemopoietic stem cells. J. Clin. Invest. 76: 1613-1621.

Sporn, M.B. and G.J. Todaro. 1980. Autocrine secretion and malignant transformation of cells. N. Engl. I. Med. 303: 878880.

Stanley, E.R. and P.T. Jubinsky. 1984. Factors affecting growth and differentiation of hemopoietic cells in culture. Clin. Hematol. 13: 329-336.

Suda, T., J. Suda, M. Ogawa, and J.N. Ihle. 1985. Permissive role of interleukin 3 (IL3) in proliferation and differentiation of multipotential hemopoietic progenitors in culture. $J$. Cell Physiol. 124: 182-190.

Tomonaga, M., D.W. Golde, and J.C. Gasson. 1986. Biosynthetic (recombinant) human granulocyte-macrophage colony-stimulating factor: Effect on normal bone marrow and leukemia cell lines. Blood 67: 31-36.

Wang, E.A., G.G. Wong, and S.C. Clark. 1985. Human recombinant granulocyte-macrophage colony-stimulating factor: A multilineage hematopoietin. Science 230: 1171-1173.

Wong, P.M.C., B.J. Clark, D.H. Carr, and D.H.K. Chui. 1982. Adult hemoglobins are synthesized in erythroid colonies in vitro derived from murine circulating hemopoietic progenitor cells during embryonic development. Proc. Natl. Acad. Sci. 79: 2952-2956.

Wong, P.M.C., S.W. Chung, J.S. White, S.M. Reicheld, M. Patterson, B.J. Clark, and D.H.K. Chui. 1983. Adult hemoglobins are synthesized in murine fetal hepatic erythropoietic cells. Blood 62: 1280-1288.

Wong, P.M.C., R.K. Humphries, T.R. Chen, and C.J. Eaves. 1985. Evidence for a multistep pathogenesis in the generation of tumorigenic cell lines from hemopoietic colonies exposed to Abelson virus in vitro. Exp. Hematol. (in press).

Wong, P.M.C., S.W. Chung, S.M. Reicheld, and D.H.K. Chui. 1986. Hemoglobin switching during murine embryonic development: Evidence for two populations of embryonic erythropoietic progenitor cells. Blood 67: 716-721. 


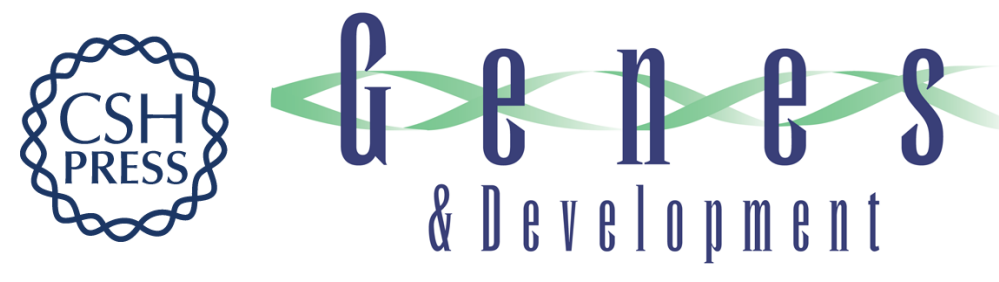

\section{Retroviral transfer and expression of the interleukin-3 gene in hemopoietic cells.}

P M Wong, S W Chung and A W Nienhuis

Genes Dev. 1987, 1:

Access the most recent version at doi:10.1101/gad.1.4.358

References This article cites 32 articles, 18 of which can be accessed free at:

http://genesdev.cshlp.org/content/1/4/358.full.html\#ref-list-1

License

Email Alerting Receive free email alerts when new articles cite this article - sign up in the box at the top Service right corner of the article or click here.

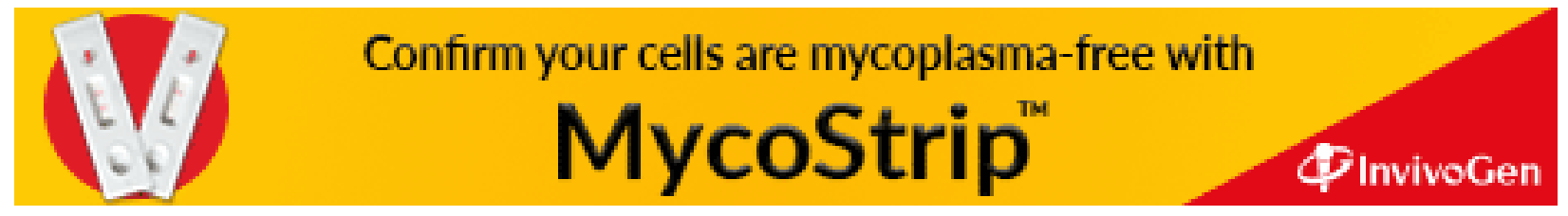

